\title{
Studi Optimasi Waktu dan Biaya dengan Metode Time Cost Trade Off pada Proyek Konstruksi Pembangunan Gedung Olah Raga (Gor)
}

(Study on Cost and Time Optimization using Duration Cost Trade Off Method on Sport Center Building Project)

\author{
MANDIYO PRIYO, MEIKI RISA ANGGRIANI PARIDI
}

\begin{abstract}
Cost and time analysis are most important on a construction project. Optimal Time and minimal cost become standard to make profit benchmarks on a project. Therefore, it is necessary to optimize cost and time by looking for work items that are included in the critical path. The purpose of this study is to know the change of cost and time due to the addition of working time, change of cost and time due to the addition of employee, So it will be compared from all two to get the minimum cost with the optimum duration.The data used in this study is secondary data obtained from contractor implementing. Data analysis using time cost trade off method with Microsoft project 2010 program. The results of the study, from the time cost trade off with the addition of 1 hours of work per day conducted on first day on critical jobs during the project, obtained the reduction in the cost of IDR 39,552,394.71 and the reduction in the duration of 36.18 days. Addition of 2 hours of work per day obtained the reduction in the cost of IDR $57,532,834.66$ and and the reduction in the duration of 62.61 days. Addition of 3 hours of work per day obtained the reduction in the cost of IDR $69,392,147,01$ and and the reduction in the duration of 82.48 days. Meanwhile, for the addition of employee for 1 hours obtained the reduction in the cost of IDR 52.497.085,35 and the reduction in the duration of 36.18 days. Addition of employee for 2 hours obtained the reduction in the cost of IDR 91,349,394.80 and the reduction in the duration of 62.61 days. Addition of employee for 3 hours obtained the reduction in the cost of IDR $120,645,301,55$ and the reduction in the duration of 82,48 days. So that, the optimal time and cost occur when addition employee is incurred for 3 hours, compared to overtime and overdue. Namely with the optimal cost of the project of IDR 2,418,408,305.45 and the optimal duration of the project for 57.52 days.
\end{abstract}

Keywords: Microsoft Project 2010, Time Cost Trade Off, Cost, Time.

\section{PENDAHULUAN}

Keberhasilan dan kegagalan suatu proyek dipengaruhi oleh waktu serta biaya. Keduanya dijadikan tolok ukur keberhasilan suatu proyek, biasanya akan terlihat pada waktu penyelesaian yang singkat, biaya minimal, akan tetapi mutu yang dihasilkan tetap sesuai yang direncanakan. Pengelolaan suatu proyek dilakukan secara sistematis untuk memastikan waktu pelaksanaan sesuai dengan yang direncanakan atau bahkan lebih cepat sehingga memberikan keuntungan pada biaya yang dikeluarkan. Serta, menghindari dari adanya denda akibat keterlambatan penyelesaian proyek.

Optimasi waktu dan biaya sangat penting untuk diketahui pada perencanaan suatu proyek konstruksi. Waktu dan biaya yang optimal maka pelaksanaan proyek dapat mendapatkan keuntungan maksimal. Untuk bisa mendapatkan hal tersebut maka perlu dilakukan optimasi waktu dan biaya, yaitu pembuatan jaringan kerja proyek (network), mencari kegiatankegiatan yang kritis dan menghitung durasi proyek serta mengetahui jumlah sumber daya (resources). 
Penelitian ini membahas tentang optimasi waktu dan biaya pada Proyek Pembangunan Gedung Olah Raga (Gor) dengan metode penambahan jam kerja (lembur) dan metode penambahan tenaga kerja.

Dwijono (2017) menyebutkan bahwa percepatan waktu setiap kegiatan dalam suatu proyek (crashing project time) dari waktu normalnya, pasti menyebabkan waktu selesainya proyek menjadi lebih cepat. Tetapi percepatan waktu kegiatan-kegiatan ini juga akan mempengaruhi proyek segi biaya khususnya untuk setiap kegiatan yang waktunya dipercepat, menjadi lebih tinggi, sehingga secara total biaya proyek menjadi lebih besar daripada biaya normalnya. Menurut Frederika (2010), durasi percepatan maksimum dibatasi oleh luas proyek atau lokasi kerja, namun ada empat faktor yang dapat dioptimumkan untuk melaksanakan percepatan suatu aktivitas, yaitu meliputi penambahan jumlah tenaga kerja, penjadwalan lembur, penggunaan alat berat, dan pengubahan metode konstruksi di lapangan. Pawiro, dkk. (2014) menyatakan bahwa pada setiap pelaksanaan proyek perlu adanya penanganan manajemen penjadwalan proyek yang baik. Suatu proyek dikatakan baik jika penyelesaian proyek tersebut efisien ditinjau dari segi waktu, biaya dan mutu. Menurut Khodijah, dkk. (2013) Dalam sebuah jaringan kerja dapat saja terdiri dari beberapa lintasan kritis. Selain lintasan kritis terdapat lintasan lain yang mempunyai jangka waktu yang lebih pendek yang dinamakan float. Float memberikan sejumlah kelonggaran waktu dan elastisitas pada sebuah jaringan kerja dan dipakai pada waktu penggunaan jaringan kerja dalam praktek.

Ada beberapa alternatif yang dapat digunakan dalam melakukan percepatan durasi penyelesaian proyek, yaitu penambahan jam kerja, pembagian giliran kerja, penambahan tenaga kerja, penambahan alat bantu dan penggantian metode pelaksanaan.

\section{Manajemen Proyek}

Soeharto (1995) menyebutkan bahwa manajemen proyek adalah melaksanakan, mengorganisir, memimpin, mengendalikan sumber daya perusahaan untuk mencapai sasaran jangka pendek yang telah ditentukan. Dipohusodo (1996) menyebutkan perencanaan proyek dimulai dari masalah-masalah pokok program pembangunan, menyusun strategi yang lebih luas, dan kemudian memilih proyek- proyek yang akan mencapai tujuan-tujuan program yang lebih luas. Untuk mendukung maksud tersebut, yaitu merencanakan proyekproyek yang merupakan bagian dari kerangka strategi program, diperlukan cara-cara analisis sitematis, sederhana, mudah dikomunikasikan, dan didasarkan pada suatu kerangka pemikiran logis. Pendekatan dapat dilihat pada bagan Gambar 1.

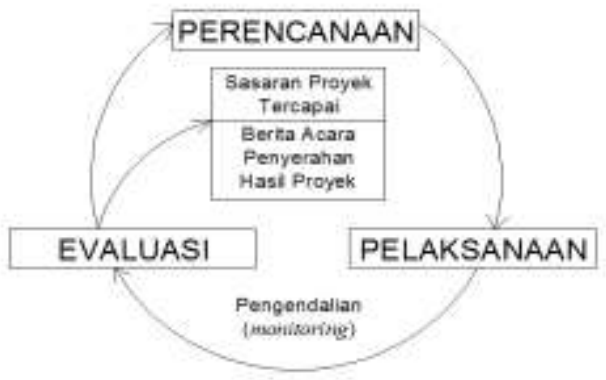

GAMBAR 1. Mekanisme Manajemen Proyek (Dipohusodo, 1996)

Telaumbanua (2017) menjelaskan bahwa Tujuan utama mempelajari manajemen adalah untuk memperoleh suatu cara atau teknik yang baik untuk dilakukan atau diterapkan agar sumber- baik. Manajemen yang baik mengandung pengertian sumber yang terbatas misalnya modal, tenaga dan sebagainya dapat diatur sehingga memperoleh hasil atau pemasukan (input) yang efektif dan efisien karena sistem pengaturannya tertata dengan efektifitas dan efisiensi.

\section{Network Planning}

Suatu kegiatan yang berupa rangkaian penyelesaian pekerjaan haruslah direncanakan dengan sebaik-baiknya. Apabila memungkinkan semua kegiatan dapat diselesaikan secara efisien. Semua kegiatankegiatan tersebut diharapkan dapat selesai dengan cepat serta terintegrasi dengan aktivitas yang lainnya. Dengan adanya network, manajemen dapat menyusun perencanaan penyelesaian proyek. Dengan waktu dan biaya yang paling efisien.

\section{Network Planning}

adalah suatu hubungan ketergantungan antar variabel-variabel yang digambarkan dalam suatu diagram network. Sehingga pekerjaan yang harus didahulukan akan diketahui atau pekerjaan yang memerlukan penambahan jam kerja maupun penambahan tenaga kerja dapat diketahui pula. Agar dapat mendapatkan waktu dan biaya yang paling efisien. 


\section{Biaya Total Proyek}

Pada kenyataannya biaya proyek terdiri dari biaya langsung (direct cost) dan biaya tidak langsung (indirect cost). Simatupang (2015) menyebutkan bahwa biaya langsung adalah biaya yang diperlukan langsung untuk mendapatkan sumber daya yang akan dipergunakan untuk penyelesaian proyek. Ketika durasi proyek ditentukan/dipercepat, biaya langsung akan lebih tinggi dibanding durasi proyek yang dikembangkan dari waktu normal ideal untuk aktivitas.

Menurut Ikhtisholiyah (2017), biaya tidak langsung adalah biaya yang berhubungan dengan pengawasan, pengarahan kerja dan pengeluaran umum diluar biaya konstruksi, biaya ini disebut juga biaya overhead. Biaya ini tidak tergantung pada volume pekerjaan tetapi tergantung pada jangka waktu pelaksanaan pekerjaan.

\section{Metode Pertukaran Waktu dan Biaya (Time Cost Trade Off)}

Di dalam perencanaan suatu proyek disamping variabel waktu dan sumber daya, variabel biaya (cost) mempunyai peranan yang sangat penting. Biaya (cost) merupakan salah satu aspek penting dalam manajemen, dimana biaya yang timbul harus dikendalikan seminim mungkin. Pengendalian biaya harus memperhatikan faktor waktu, karena terdapat hubungan yang erat antara waktu penyelesaian proyek dengan biaya-biaya proyek yang bersangkutan.

Sering terjadi suatu proyek harus diselesaikan lebih cepat daripada waktu normalnya. Dalam hal ini pimpinan proyek dihadapkan dalam hal masalah bagaimana mempercepat penyelesaian proyek dengan biaya minimum. Oleh karena itu perlu dipelajari terlebih dahulu hubungan waktu dan biaya. Analisis mengenai pertukaran waktu dan biaya disebut dengan Time Cost Trade Off.

Di dalam analisa time cost trade off ini dengan berubahnya waktu penyelesaian proyek maka berubah pula biaya yang akan dikeluarkan. Apabila waktu pelaksanaan dipercepat maka biaya langsung proyek akan bertambah dan biaya tidak langsung proyek akan berkurang.

Ada beberapa macam cara yang dapat digunakan untuk melaksanakan percepatan penyelesaian waktu proyek. Cara-cara tersebut antara lain:

a. Penambahan jumlah jam kerja (lembur)

b. Penambahan tenaga kerja

c. Pergantian atau penambahan peralatan d. Pemilihan sumber daya manusia yang berkualitas

e. Penggunaan metode konstruksi yang efektif

\section{Produktivitas Pekerja}

Priyo dan Sumanto (2016) menyebutkan bahwa produktivitas didefinisikan sebagai rasio antara output dan input, atau dapat dikatakan sebagai rasio antara hasil produksi dengan total sumber daya yang digunakan.

Menurut Wowor (2013), output dapat dilihat dari kuantitas pekerjaan yang telah dilakukan seperti meter kubik galian atau timbunan, ataupun meter persegi untuk plesteran. Sedangkan input merupakan jumlah sumber daya yang dipergunakan seperti tenaga kerja, peralatan dan material. Karena peralatan dan material biasanya bersifat standar, maka tingkat keahlian tenaga kerja merupakan salah satu faktor penentu produktivitas.

\section{Pelaksanaan Penambahan Jam Kerja}

Kareth (2012) menyebutkan bahwa pengaturan waktu atau penjadwalan dari kegiatan-kegiatan yang terlibat didalamnya dimaksudkan agar suatu proyek dapat berjalan dengan lancar serta efektif. Oleh karena itu, pihak pelaksana dari suatu proyek biasanya membuat suatu jadwal waktu kegiatan atau time schedule. Jadwal waktu kegiatan adalah urutan-urutan kerja yang berisi tentang :

a. Jenis pekerjaan yang akan diselesaikan

b. Waktu bilamana suatu pekerjaan dimulai dan diakhiri.

Salah satu strategi untuk mempercepat waktu pelaksanaan proyek adalah dengan menambah jam kerja (lembur) para pekerja. Penambahan jam kerja bisa dilakukan dengan melakukan penambahan 1, 2, 3, dan 4 jam sesuai dengan waktu penambahan yang diinginkan. Semakin besar penambahan jam lembur dapat menimbulkan penurunan produktivitas. Indikasi dari produktivitas pekerja terhadap penambahan jam kerja (lembur) dapat dilihat pada Gambar 2.

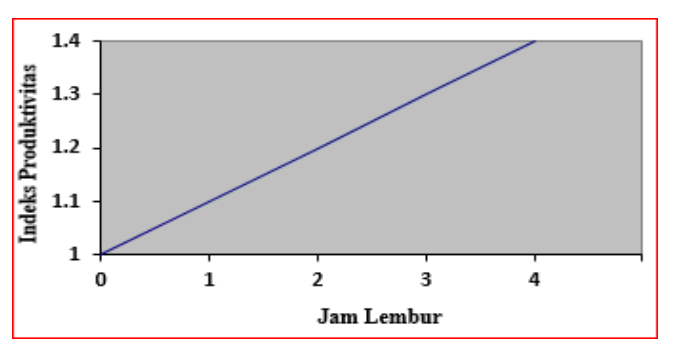

GAMBAR 2. Grafik Indikasi Penurunan Produktivitas Akibat Penambahan Jam Kerja (Soeharto, 1995) 
Dari uraian di atas dapat ditulis sebagai berikut:

Produktivitas harian $=\frac{\text { Volume }}{\text { Durasi normal }}$

Produktivitas tiap jam $=\frac{\text { Produktivitas harian }}{\text { Jam kerja perhari }}$

Produktivitas harian sesudah crash

$=($ Jam kerja perhari $\times$ Produktivitas tiap jam $)$

$+(\mathrm{a} \times \mathrm{b} \times$ Produktivitas tiap jam $)$

dengan:

$\mathrm{a}=$ lama penambahan jam kerja (lembur)

$\mathrm{b}=$ koefisien penurunan produktivitas akibat penambahan jam kerja (lembur)

Nilai koefisien penurunan produktivitas tersebut dapat dilihat pada Tabel 1 .

TABel 1. Koefisien Penurunan Produktivitas

\begin{tabular}{lll}
\hline Jam & Penurunan & Prestasi \\
\hline 1 jam & 0,1 & 90 \\
2 jam & 0,2 & 80 \\
3 jam & 0,3 & 70 \\
4 jam & 0,4 & 60 \\
\hline \multicolumn{3}{c}{ (Sumber : Soeharto, 1995) }
\end{tabular}

\section{Crash duration}

$=\frac{\text { Volume }}{\text { Produktivitas harian sesudah crash }}$

\section{Pelaksanaan Penambahan Tenaga Kerja}

Dalam penambahan jumlah tenaga kerja yang perlu diperhatikan adalah ruang kerja yang tersedia apakah terlalu sesak atau cukup lapang, karena penambahan tenaga kerja pada suatu aktivitas tidak boleh mengganggu pemakaian tenaga kerja untuk aktivitas yang lain yang sedang berjalan pada saat yang sama. Selain itu, harus diimbangi pengawasan karena ruang kerja yang sesak dan pengawasan yang kurang akan menurunkan produktivitas pekerja.

Menurut Priyo dan Sumanto (2016), perhitungan untuk penambahan tenaga kerja dirumuskan sebagai berikut ini :

Jumlah tenaga kerja normal

$=\frac{(\text { Koefisien tenaga kerja } \times \text { Volume })}{\text { Durasi normal }}$

Jumlah tenaga kerja dipercepat $=\frac{(\text { Koefisien tenaga kerja } \times \text { Volume })}{\text { Durasi dipercepat }}$
Dari rumus di atas maka akan diketahui jumlah pekerja normal dan jumlah penambahan tenaga kerja akibat percepatan durasi proyek.

\section{Biaya Tambahan Pekerja ( Crash Cost)}

Penambahan waktu kerja akan menambah besar biaya untuk tenaga kerja dan biaya normal tenaga kerja. Berdasarkan Keputusan Menteri Tenaga Kerja dan Transmigrasi Republik Indonesia Nomor KEP. 102/MEN/VI/2004 pasal 3, pasal 7, dan pasal 11 diperhitungkan bahwa upah penambahan kerja bervariasi. Pada penambahan waktu kerja satu jam pertama, pekerja mendapatkan tambahan upah 1,5 kali upah perjam waktu normal pada penambahan jam kerja berikutnya maka pekerja akan mendapatkan 2 kali upah perjam waktu normal.

Perhitungan untuk biaya tambahan pekerja akibat jam lembur dapat dirumuskan sebagai berikut :

Normal upah pekerja perhari

$=$ Produktivitas harian $\times$ harga satuan upah pekerja

Normal upah biaya perjam

$=$ Produktivitas perjam $\times$ harga satuan upah pekerja

Biaya lembur pekerja

$=1,5 \times$ upah sejam normal untuk penambahan jam kerja (lembur) pertama $+2 \times \mathrm{n} \times$ upah sejam normal untuk penambahan jam kerja (lembur) berikutnya.

dengan :

$\mathrm{n}=$ jumlah penambahan jam kerja (lembur)

Crash cost pekerja perhari

$=($ jam kerja perhari $\times$ normal cost pekerja $)+(\mathrm{n}$ $\times$ biaya lembur perjam)

Cost Slope

$=\frac{\text { Crash cost }- \text { normal cost }}{\text { Durasi normal-durasi crash }}$

Perhitungan untuk biaya tambahan akibat penambahan tenaga kerja dapat dirumuskan sebagai berikut :

Normal ongkos pekerja perhari sesuai dengan harga satuan setiap daerah

Biaya penambahan pekerja

$=$ jumlah pekerja $\times$ upah normal pekerja

Perhari

Crash cost pekerja

= (biaya total pekerja yang dipercepat - biaya total pekerja normal)

Cost slope

$=\frac{\text { Crash cost }- \text { Normal cost }}{\text { Durasi normal-Durasi crash }}$ 


\section{Hubungan Antara Biaya dan Waktu}

Biaya total proyek sama dengan penjumlahan dari biaya langsung dan biaya tidak langsung. Biaya total proyek sangat bergantung pada waktu penyelesaian proyek. Hubungan antara biaya dengan waktu dapat dilihat pada Gambar 3. Titik A pada gambar menunjukan kondisi normal, sedangkan titik B menunjukan kondisi dipercepat. Garis yang menghubungkan antar titik tersebut disebut kurva waktu dan biaya. Gambar 3 memperlihatkan bahwa semakin besar penambahan jumlah jam kerja (lembur) maka akan semakin cepat waktu penyelesaian proyek, akan tetapi sebagai konsekuensinya maka terjadi biaya tambahan yang akan dikeluarkan semakin besar. Gambar 4 menunjukan hubungan biaya langsung, biaya tak langsung dan total biaya dalam suatu grafik dan terlihat bahwa optimum didapat dengan mencari total biaya proyek yang terkecil.

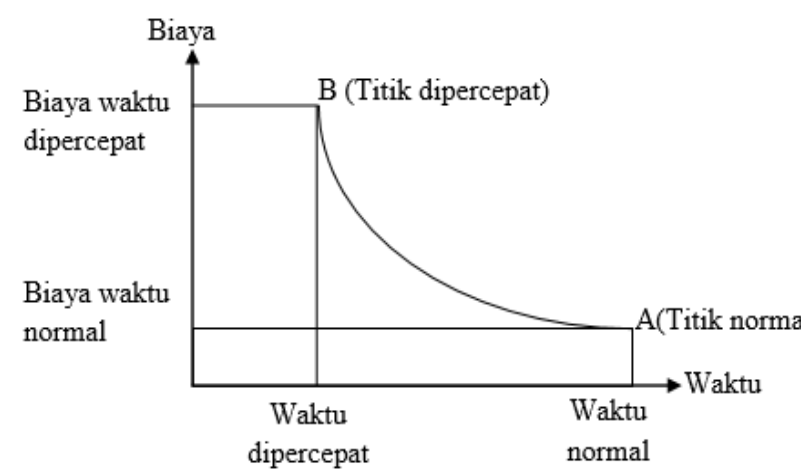

GAMBAR 3. Grafik hubungan waktu-biaya normal dan dipercepat untuk suatu kegiatan

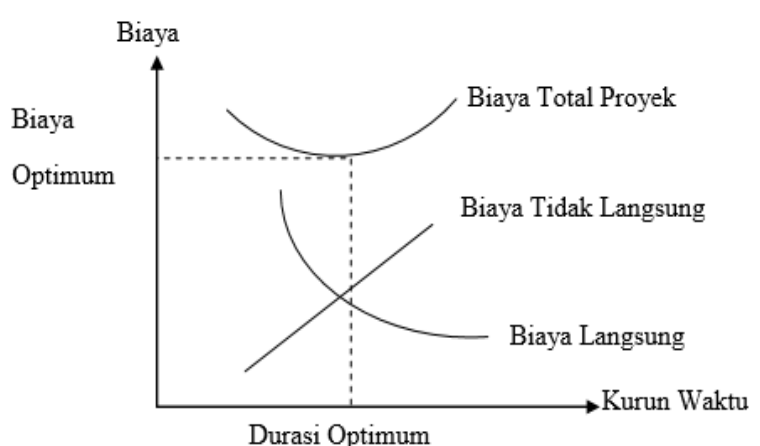

GAMBAR 4. Grafik hubungan waktu dengan biaya total, biaya langsung, dan biaya tidak langsung (Soeharto, 1995).

\section{Program Microsoft Project 2010}

Microsoft Project merupakan software administrasi proyek yang digunakan untuk melakukan perencanaan, pengelolaan, pengawasan dan pelaporan data dari suatu proyek. Kemudahan penggunaan dan keleluasaan lembar kerja serta cakupan unsurunsur proyek menjadikan software ini sangat mendukung proses administrasi sebuah proyek.

$\begin{aligned} & \text { Microsoft } \\ & \text { manajemen project memberikan }\end{aligned} \begin{array}{r}\text { unsur } \\ \text { proyek yang baik, dengan } \\ \text { memadukan kemudahan pengguna }\end{array}$
(user),
kemampuan, dan fleksibilitas sehingga
penggunanya dapat mengelola proyek lebih
efisien dari segi biaya maupun waktu.
Pengelolaan proyek konstruksi membutuhkan
waktu yang panjang dan ketelitian yang besar.
Microsoft Project dapat menunjang dan
membantu sebuah pengelolaan proyek
konstruksi sehingga didapat suatu data yang
lebih akurat.

Keunggulan dari Microsoft Project adalah kemampuan menangani perencanaan pada suatu kegiatan, pengorganisasan dan pengendalian waktu serta biaya yang mengubah input data menjadi output yang direncanakan. Input mencakup unsur-unsur manusia, material, mata uang, mesin/alat, dan kegiatan. Selanjutnya, diproses menjadi suatu hasil yang maksimal untuk mendapat informasi yang diinginkan sebagai pertimbangan guna pengambilan keputusan.

Keuntungan Microsoft Project adalah dapat melakukan penjadwalan produksi secara efektif dan efisien, dapat diperoleh secara langsung informasi biaya selama periode, mudah dilakukan modifikasi dan penjadwalan produksi yang tepat dan mudah dihasilkan dengan waktu yang relatif cepat. Jenis metode manajemen proyek yang dikenal saat ini, antara lain Gantt Chart, CPM (Critical Path Method), dan PERT (Program Evaluation Review Technique).

Microsoft Project adalah gabungan dari ketiga metode tersebut. Microsoft Project juga merupakan sistem perencanaan yang membantu dalam penyusunan jadwal (scheduling) suatu proyek konstruksi atau rangkaian pekerjaan. Microsoft Project juga membantu melakukan pencatatan dan pemantauan terhadap pengguna sumber daya (resources), baik berupa sumber daya manusia maupun yang berupa peralatan.

Program Microsoft Project memiliki beberapa tampilan layar, namun sebagai default setiap membuka file baru, maka akan tertampil Gantt Chart View seperti pada Gambar 5. 


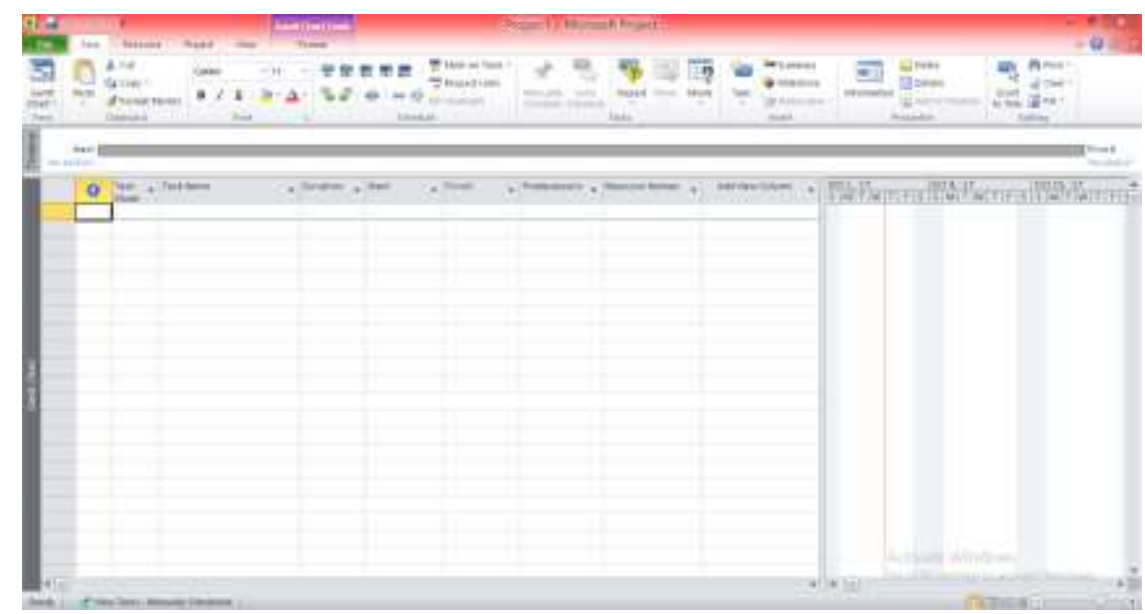

GAMBAR 5. Tampilan layar Gantt Chart View

\section{METODE PENELITAN}

\section{Pengumpulan Data}

Penelitian ini dilakukan pada Proyek Pembangunan Gedung Olah Raga. Data dan Informasi yang didapat dari pelaksanaan suatu proyek konstruksi sangat bermanfaat untuk mengevaluasi optimasi dari waktu dan biaya secara keseluruhan. Data sekunder adalah data yang diperlukan yaitu berasal dari instasi yang terkait seperti konsultan, kontraktor, dan lainlain. Beberapa variabel yang mempengaruhi pada optimasi biaya dan waktu ini adalah variabel waktu dan variabel biaya.

a. Variabel waktu

Meliputi data yang diperoleh dari kontraktor pelaksana maupun dari konsultan pengawas. Data cumulative progress (kurva S), meliputi :
1) Jenis kegiatan
2) Durasi kegiatan
3) Persentase kegiatan
4) Rekapitulasi perhitungan biaya proyek

b. Variabel biaya

Keseluruhan data yang berpengaruh pada variabel biaya, didapat dari kontraktor pelaksana. Data yang diperlukan adalah sebagai berikut :

1) Rencana anggaran biaya (RAB), meliputi:

a) Total biaya normal

b) Durasi normal

2) Daftar harga upah dan bahan

3) Gambar rencana proyek

Data yang digunakan adalah data primer dan data sekunder yang berupa hasil analisis menggunakan microsoft project, meliputi :
1) Daftar bahan dan upah tenaga

2) Rencana anggaran biaya

3) Time schedule

4) Estimasi waktu dalam microsoft project

5) Data biaya normal

\section{Analisis Data}

Analisis data yang dilakukan dengan bantuan program Microsoft Project 2010. Data akan input dan dianalisis dalam program, sehingga program akan menganalisis hasil dari data tersebut secara otomatis sesuai dengan rumus kalkulasi yang ada dalam program Microsoft Project 2010.

Pada proses input data tahap analisis ini menggunakan dua tahapan, yaitu pertama dengan menyusun jadwal rencana dan biaya proyek (baseline) serta memasukkan durasi optimasi penambahan jam kerja (lembur).

\section{Tahapan dan Prosedur Penelitian}

Suatu penelitian harus dilaksanakan secara sistematis dan menggunakan urutan yang jelas serta teratur, sehingga akan diperoleh hasil yang diharapkan akan sesuai. Maka dari itu, pelaksanaan penelitian dibagi dalam beberapa tahap, meliputi:

Tahap 1 : Tahap Persiapan

Sebelum penelitian dilakukan perlu adanya studi

literatur untuk memperdalam ilmu yang berkaitan dengan topik penelitian. Kemudian menentukan rumusan masalah sampai dengan kompilasi data.

Tahap 2 : Tahap Pengumpulan Data Data proyek yang diperlukan untuk pembuatan laporan, yaitu :

1. Rencana anggaran biaya (RAB) 
2. Analisa harga satuan bahan

3. Time schedule

Tahap 3 : Tahap Analisis percepatan dengan aplikasi program dan pembahasan

Dari data yang telah didapat kemudian dilakukan analisis menggunakan program microsoft excel dan microsoft project 2010. Pertama data akan di input pada program untuk perencanaan dan update perencanaan dengan data pelaksanaan, perhitungan keseluruhan dipusatkan pada kegiatan yang masuk dalam lintasan kritis yang mempunyai nilai cost slope terendah. Kemudian dibandingkan antara hasil analisa percepatan yang berupa biaya proyek sebelum dan setelah percepatan dengan biaya denda akibat keterlambatan.

Tahap 4 : Kesimpulan

Kesimpulan disebut juga tahap pengambilan keputusan. Pada tahap ini, data yang sudah dianalisis secara keseluruhan dibuat kesimpulannya yang berhubungan dengan tujuan penelitian.

Tahapan penelitian secara skematis dapat dilihat dalam diagram alir pada Gambar 6 .

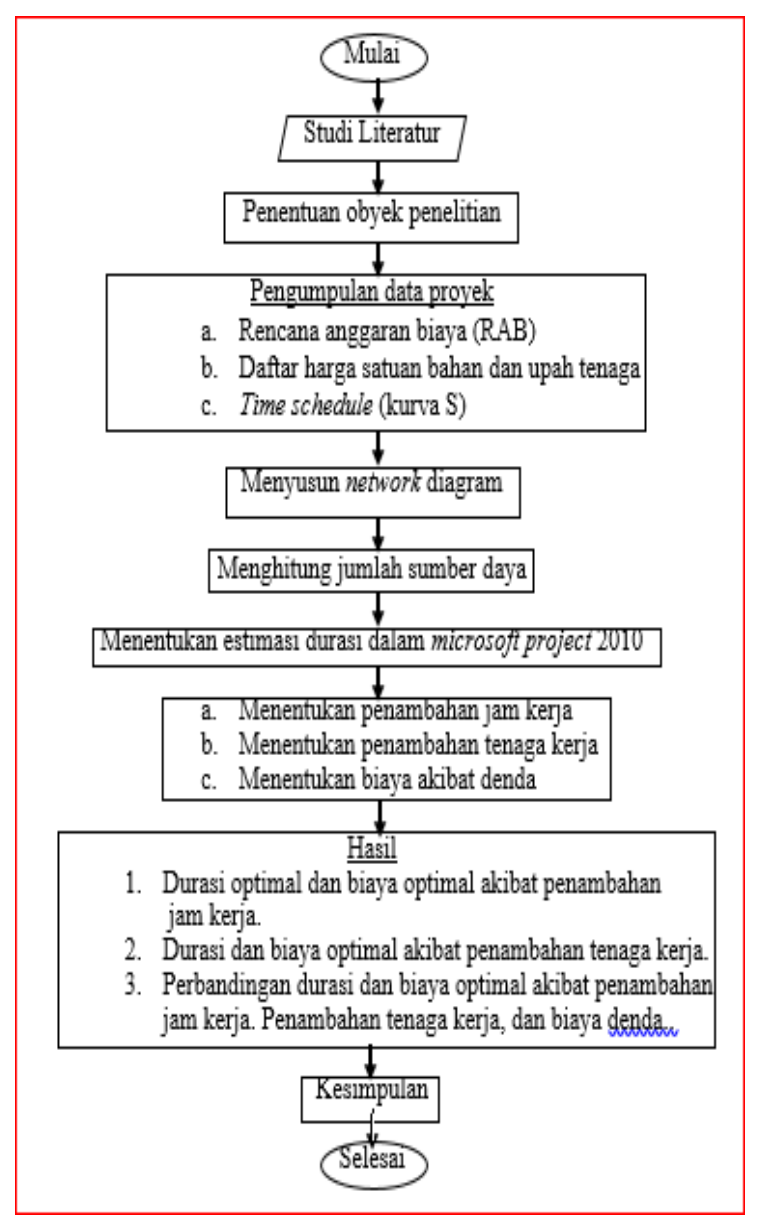

GAMBAR 6. Bagan alir penelitian

\section{HASIL DAN PEMBAHASAN}

1. Data Umum Proyek

Adapun gambaran umum pada Proyek Pembangunan Gedung Olah Raga (Gor), adalah sebagai berikut :

Pemilik Proyek : X

Konsultan Supervisi : PT. Y

Kontraktor : PT. Z

Anggaran $\quad: R p$ 2.539.053.607,00

Waktu Pelaksanaan : 140 hari kerja

Tanggal Pekerjaan Dimulai : 02 Januari 2017

Tanggal Pekerjaan Selesai : 26 April 2017

\section{Daftar Kegiatan Kritis}

Daftar kegiatan kritis yang didapat pada hasil analisis di Microsoft Project 2010 pada kondisi normal dapat dilihat pada Tabel 2.

TABEL 2. Daftar kegiatan-kegiatan kritis

\begin{tabular}{|c|c|c|c|}
\hline $\mathrm{N}_{0}$ & Kode & Kegintan & $\begin{array}{l}\text { Durasi } \\
\text { (hari) }\end{array}$ \\
\hline 1 & GTPCS & Pel: Galina tanah pile cap dan sloof & 14 \\
\hline 2 & PBP & Pemberizn Pel Beitu Bored Pila & 28 \\
\hline 3 & $\mathrm{PPCl}$ & Pembeizn Pel Betun Pla cap PCl & 14 \\
\hline 4 & $\mathrm{BPCl}$ & Belisting Pel:Beton Ple cap PC1 & $?$ \\
\hline 5 & $\mathrm{CPC} 2$ & BetwoK225 Pek Betsu Ple cap PC2 & $?$ \\
\hline 6 & PPC2 & Pembeizn Pel Beitun Ple cap PC2 & 14 \\
\hline 7 & $\mathrm{BPC2}$ & Belising Pel:Beton Pile cap PC2 & $?$ \\
\hline 8 & BBS.S1 & Belisting Pek. Balok Sloof S1=20150 & 14 \\
\hline 9 & BBS.S2 & Belising Pek Balok Sloof S2=15/20 & 14 \\
\hline 10 & BBPIP & Belising Pek. Betton Plat Laparan & 7 \\
\hline 11 & BPTG & Belising Pel. Plat tangen & $?$ \\
\hline 12 & BBB-BO & Belising Pel. Ballk bordes B $=15 / 30$ & $?$ \\
\hline 13 & BPB & Belisting Pek Plat bordes & 7 \\
\hline 14 & BBL-B2 & Belisting Pek: BalokL Latai Bl=20/35 & $?$ \\
\hline 15 & BBL-33 & 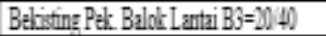 & 7 \\
\hline 16 & BBL-BL1 & Belising Pek. BaldkL antai BLI=10155 & 7 \\
\hline 17 & BBL-BL2 & Belising Pek BaldkLantai BL2=835 & 7 \\
\hline 18 & BBPII & Beliting Pel: Betou Plat Lantai & 14 \\
\hline 19 & BPTP & Belisting Pek Plyt Topian & 7 \\
\hline 20 & CKPLLI2 & Beton K25 Pel: Kolon Praltis & 7 \\
\hline 21 & PKP-LI2 & Pembesian Pel Kolom Pralitis & 14 \\
\hline 22 & BKP.LI2 & Belising Pek Bolvan Praltis & 7 \\
\hline 23 & PX1-LI2 & Pembeizn Pel Kolom $\mathrm{Kl}=4060$ & 28 \\
\hline 24 & CK2LII2 & Beton K225 Pek Kolon K2=40.40 & 7 \\
\hline 25 & PX2-LI2 & Pembeisn Pel Kalom KI $=4040$ & 14 \\
\hline 26 & BK2-LI2 & 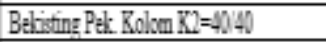 & $?$ \\
\hline 27 & CR1-LT3 & Beton K225 Pel Kolon K1=4060 & $?$ \\
\hline 28 & PX1-LT3 & Pembeizan Pel Kolom K1=40.50 & 21 \\
\hline 29 & BK1-LI3 & Belising Pel. Bolvan KI=4060 & 14 \\
\hline 30 & PRP-LT3 & Pemberisn Pel Kolom Praltis & $?$ \\
\hline 31 & BKP.LT3 & Belisifing Pel. Rolon Praltis & 7 \\
\hline 32 & CPLR & Betou K205 Pek. Plat lantai (wantol) & $?$ \\
\hline 33 & PPLR & Pembeisn Pel Pat lanti (knatrol) & 7 \\
\hline 34 & BPLK & Belisting Pek. Plat lantai (lourtol) & 7 \\
\hline
\end{tabular}

Tabel 2 diatas menjabarkan kegiatan-kegiatan kritis yang akan dipercepat adalah kegiatan yang memiliki unsur tenaga kerja. Alasan dipilihnya kegiatan-kegiatan yang akan 
dipercepat adalah kegiatan kritis tersebut, yaitu

a. Kegiatan kritis yang dipilih memiliki tenaga kerja (resource work), sehingga dapat dipercepat dengan mengolah resource work.

b. Pada kegiatan kritis akan dilakukan percepatan menggunakan penambahan jam kerja (lembur) atau dengan penambahan tenaga kerja. Apabila dilakukan penambahan tenaga kerja, itu tidak akan berpengaruh pada penambahan jumlah tenaga kerja, karena indeks tenaga kerja pada kegiatan kritis kecil.

c. Pada kegiatan kritis apabila dilakukan percepatan akan berpengaruh pada anggaran biaya tidak langsung.

Percepatan kegiatan kritis akan mempercepat durasi proyek secara keseluruhan.

3. Biaya Langsung dan Biaya Tidak Langsung

Menentukan biaya tidak langsung berdasarkan hasil Studi Praktek Estimasi Biaya Tidak Langsung pada Proyek Konstruksi dapat dilihat pada Gambar 7:

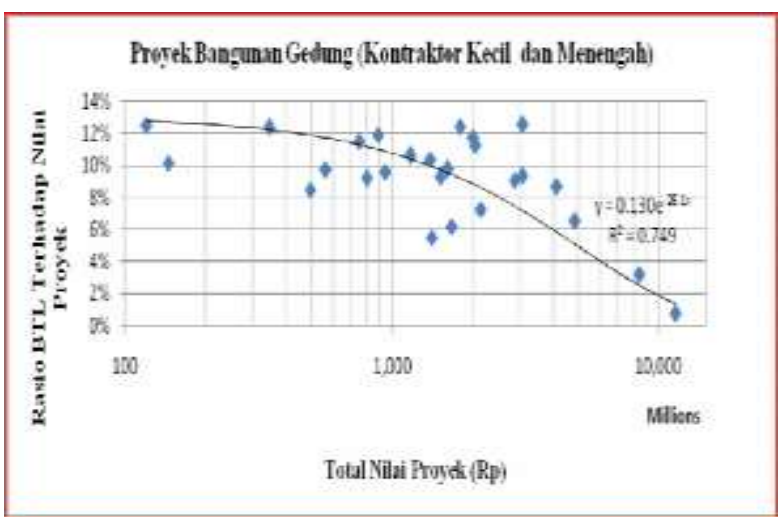

GAMBAR 7. Hubungan biaya tidak langsung dengan nilai proyek

Nilai total Proyek Pembangunan Gedung Olahraga (Gor) sebesar Rp 2,539,053,607.00, sehingga berdasarkan grafik diatas didapat persen biaya tidak langsung sebesar $8,1 \%$ dari keseluruhan nilai total proyek. Hitungan manual untuk biaya tidak langsung sebagai berikut :

Biaya tidak langsung $=8,1 \% \times 2,539,053,607$

$$
=\operatorname{Rp} 205,663,342.17
$$

Biaya tidak langsung/hari

= Biaya tidak langsung / Durasi normal proyek

$=\operatorname{Rp} 205,663,342.17 / 140$ hari

$=\operatorname{Rp} 1,469,023.87 /$ hari
Biaya Langsung

$=$ Biaya total proyek - Biaya tidak langsung

$=\operatorname{Rp} 2,539,053,607.00-\operatorname{Rp} 205,663,342.17$

$=\operatorname{Rp} 2,333,390,264.83$

\section{Penerapan Metode Time Cost Trade Off}

Penambahan jam kerja (lembur) yang digunakan 8 (delapan) jam kerja normal dengan 1 (satu) jam istirahat (08.00 $\mathrm{s} / \mathrm{d} \quad 17.00)$, sedangkan untuk penambahan jam kerja dilakukan setelah selesainya jam kerja normal (17.00 s/d 20.00). Menurut keputusan Menteri Tenaga Kerja Nomor KEP.102/MEN/VI/2004 pasal 3, pasal 7, serta pasal 11, dijelaskan standar upah tenaga kerja untuk lembur adalah :

a. Waktu kerja lembur hanya dapat dilakukan maksimal 3 (tiga) jam dalam 1 (satu) hari dan 14 (empat belas) jam dalam 1 (satu) minggu.

b. Waktu kerja lembur tidak termasuk pada waktu istirahat mingguan atau hari libur resmi.

c. Memberikan makanan sekurang-kurangnya 1.400 kalori apabila kerja lembur dilakukan 3 (tiga) jam atau lebih.

d. Untuk kerja lembur pertama dibayar sebesar 1,5 kali upah sejam, sedangkan untuk setiap jam kerja lembur berikutnya harus dibayar sebesar 2 (dua) kali lipat upah sejam.

1. Penambahan Jam Kerja (Lembur)

Contoh perhitungan sebagai berikut :

Pekerjaan = Pembesian beton bored pile

Volume $\quad=8294,451 \mathrm{~kg}$

Durasi normal $/$ hari $=28$ hari

Durasi normal $/ \mathrm{jam} \quad=28 \times 8$

$$
=224 \mathrm{jam}
$$

Produktivitas jam normal $=\frac{\text { Volume }}{\text { Durasi normal }}$

$$
\begin{aligned}
& =\frac{8294,451}{224} \\
& =37,03 \mathrm{~kg}
\end{aligned}
$$

Durasi percepatan $1 \mathrm{jam}=$ 8294,451

$(37,03 \times 8)+(1 \times 0,9 \times 37,03)$

$$
=25,17 \text { hari }
$$

Maksimal crashing

$=$ durasi normal - durasi percepatan $1 \mathrm{jam}$

$=28-25,17$

$=2,83$ hari

Hasil perhitungan durasi crashing manual diatas sesuai dengan hasil analisis pada Microsoft Project 2010, untuk durasi dan biaya crashing pada item pekerjaan lain dapat dilihat pada Tabel 3. 
TABEl 3. Perhitungan hasil Microsoft Project 2010

(durasi percepatan dan biaya percepatan)

\begin{tabular}{|c|c|c|c|c|c|c|}
\hline \multirow{2}{*}{ Kode } & \multicolumn{2}{|r|}{ Normal } & \multirow{2}{*}{ Crashing } & \multicolumn{2}{|c|}{ Percepatan } & \multirow{2}{*}{ Selisih } \\
\hline & Durasi & Biaya & & Durasi & Biaya & \\
\hline GTPCS & 14 & $5,157,600.00$ & 1.42 & 12.58 & $5,492,050.00$ & $334,450.00$ \\
\hline PBP & 28 & $113,848,881.00$ & 2.83 & 25.17 & $114,809,591.00$ & $960,710.00$ \\
\hline $\mathrm{PPCl}$ & 14 & $27,513,876.00$ & 1.42 & 12.58 & $27,746,792.00$ & $232,916.00$ \\
\hline $\mathrm{BPCl}$ & 7 & $11,134,550.00$ & 0.71 & 6.29 & $11,453,459.00$ & $318,909.00$ \\
\hline $\mathrm{CPC} 2$ & 7 & $3,830,928.00$ & 0.71 & 6.29 & $3,878,050.00$ & $47,122.00$ \\
\hline $\mathrm{PPC} 2$ & 14 & $8,056,967.00$ & 1.42 & 12.58 & $8,127,607.00$ & $70,640.00$ \\
\hline $\mathrm{BPC} 2$ & 7 & $3,493,270.00$ & 0.71 & 6.29 & $3,587,948.00$ & $94,678.00$ \\
\hline BBS-S1 & 14 & $51,369,060.00$ & 1.42 & 12.58 & $52,752,491.00$ & $1,383,431.00$ \\
\hline BBS-S2 & 14 & $3,227,540.00$ & 1.42 & 12.58 & $3,317,618.00$ & $90,078.00$ \\
\hline BBPLP & 7 & $22,463,390.00$ & 0.71 & 6.29 & $23,070,796.00$ & $607,406.00$ \\
\hline BPTG & 7 & $2,448,600.00$ & 0.71 & 6.29 & $2,503,053.00$ & $54,453.00$ \\
\hline BBB-B8 & 7 & $3,765,410.00$ & 0.71 & 6.29 & $3,848,141.00$ & $82,731.00$ \\
\hline BPB & 7 & $844,730.00$ & 0.71 & 6.29 & $872,343.00$ & $27,613.00$ \\
\hline BBL-B2 & 7 & $27,279,440.00$ & 0.71 & 6.29 & $27,879,209.00$ & $599,769.00$ \\
\hline BBL-B3 & 7 & $16,982,800.00$ & 0.71 & 6.29 & $17,349,669.00$ & $366,869.00$ \\
\hline BBL-BL1 & 7 & $20,969,870.00$ & 0.71 & 6.29 & $21,435,986.00$ & $466,116.00$ \\
\hline BBL-BL2 & 7 & $1,624,780.00$ & 0.71 & 6.29 & $1,663,330.00$ & $38,550.00$ \\
\hline BBPLT & 14 & $173,945,520.00$ & 1.42 & 12.58 & $177,385,883.00$ & $3,440,363.00$ \\
\hline BPTP & 7 & $29,984,230.00$ & 0.71 & 6.29 & $30,559,230.00$ & $575,000.00$ \\
\hline CKP-LT2 & 7 & $8,115,336.00$ & 0.71 & 6.29 & $8,205,761.00$ & $90,425.00$ \\
\hline PKP-LT2 & 14 & $15,413,328.00$ & 1.42 & 12.58 & $15,543,387.00$ & $130,059.00$ \\
\hline BKP-LT2 & 7 & $16,279,150.00$ & 0.71 & 6.29 & $16,651,859.00$ & $372,709.00$ \\
\hline PK1-LT2 & 28 & $58,863,598.00$ & 2.83 & 25.17 & $59,364,133.00$ & $500,535.00$ \\
\hline CK2-LT2 & 7 & $6,276,764.00$ & 0.71 & 6.29 & $6,345,002.00$ & $68,238.00$ \\
\hline PK2-LT2 & 14 & $12,526,499.00$ & 1.42 & 12.58 & $12,604,596.00$ & $78,097.00$ \\
\hline $\mathrm{BK} 2-\mathrm{LT} 2$ & 7 & $18,863,080.00$ & 0.71 & 6.29 & $19,260,714.00$ & $397,634.00$ \\
\hline CK1-LT3 & 7 & $18,022,344.00$ & 0.71 & 6.29 & $18,219,715.00$ & $197,371.00$ \\
\hline PK1-LT3 & 21 & $34,661,513.00$ & 2.12 & 18.88 & $34,967,313.00$ & $305,800.00$ \\
\hline BK1-LT3 & 14 & $45,157,200.00$ & 1.42 & 12.58 & $46,141,713.00$ & $984,513.00$ \\
\hline PKP-LT3 & 7 & $1,636,813.00$ & 0.71 & 6.29 & $1,648,178.00$ & $11,365.00$ \\
\hline BKP-LT3 & 7 & $1,720,280.00$ & 0.71 & 6.29 & $1,763,899.00$ & $43,619.00$ \\
\hline CPLK & 7 & $7,761,338.00$ & 0.71 & 6.29 & $7,852,545.00$ & $91,207.00$ \\
\hline PPLK & 7 & $11,287,717.00$ & 0.71 & 6.29 & $11,385,449.00$ & $97,732.00$ \\
\hline BPLK & 7 & $21,839,000.00$ & 0.71 & 6.29 & $22,274,781.00$ & $435,781.00$ \\
\hline
\end{tabular}

Contoh perhitungan upah lembur 2 jam untuk resource name pekerja, sebagai berikut :

Upah normal perhari (standart cost)

$=\operatorname{Rp} 80.000,00$

Jam kerja perhari $=8$ jam/hari

Biaya per jam $=((\operatorname{Rp~} 80.000,00) /(8 \mathrm{jam} / \mathrm{hari}))$

$=\operatorname{Rp} 10.000,00$

Lembur 2 jam

$=(1,5 \times$ Upah normal perjam $)+(2 \times 1 \times$ upah normal perjam)

$=(1,5 \times \mathrm{Rp} 10.000,00)+(2 \times 1 \times \mathrm{Rp}$ $10.000,00)$

$=\mathrm{Rp} 35.000,00$

Lembur /jam untuk 2 jam

$=((\operatorname{Rp~35.000,00)/(2~jam~}))$

$=\operatorname{Rp} 17.500,00$

TABEL 4. Upah Tenaga Kerja

\begin{tabular}{|c|c|c|c|c|c|c|}
\hline \multirow{2}{*}{$\begin{array}{l}\text { Tesaga } \\
\text { kefji }\end{array}$} & \multicolumn{2}{|c|}{ Lentor 1 jam } & \multicolumn{2}{|c|}{ Lemlkur $2 \mathrm{j}$ jm } & \multicolumn{2}{|c|}{ Lembur $3 \mathrm{jam}$} \\
\hline & 100 & perjum & 2.00 & perim & 3.00 & per jun \\
\hline Pekerga & $15,000.00$ & $15,000.00$ & $35,000.00$ & $17,500.00$ & $55,000.00$ & $18,333.13$ \\
\hline Tukane & $30,625.00$ & $20,625: 00$ & $48,125.00$ & $24,062.50$ & $75,625.00$ & $25,208.33$ \\
\hline K Tulang & $23,437,50$ & $23,437.50$ & $54,687,50$ & 27.34 .75 & 85.937 .50 & $28,645,83$ \\
\hline Mandor & $22,500.00$ & $22,500.00$ & $52,500.00$ & 26.250 .00 & $82,300.00$ & $27,500.00$ \\
\hline
\end{tabular}

Contoh perhitungan manual biaya normal dan dipercepat pada pekerjaan Pembesian Beton Bored pile pada lembur 1 jam:

Volume $=8294.451 \mathrm{~kg}$

Durasi normal $\quad=28$ hari

Durasi percepatan $\quad=25,17$ hari

Kapasitas tenaga kerja per $\mathrm{m}^{3}$

$\mathrm{Oh}=$ Orang $/$ hari

Pekerja $\quad=0,007$ Oh @ Rp 80.000,00

Tukang $=0,007$ Oh @ Rp 110.000,00

Kepala tukang $=0,0007$ Oh @ Rp 125.000,00

Mandor $=0,0004$ Oh @ Rp 120.000,00

Material

Besi beton =1,05 Kg @ Rp 11.420,00

Kawat beton $=0.15 \quad \mathrm{Kg} @ \mathrm{Rp} 18.000,00$

Perhitungan kebutuhan material :

Besi beton $=8294,451 \times 1,0500=8709,173$

Kawat beton $=8294,451 \times 0,0150=124,416$

Kebutuhan tenaga kerja

$=($ volume $\times$ koefisien $) /$ durasi
Pekerja
$=2,073$ Oh @ Rp 15.000,00
Tukang
$=2,073$ Oh @ Rp 20.625,00
Kepala tukang $=0,207$ Oh @ Rp 23.437,50
Mandor
$=0,118$ Oh@ $@$ p 22.500,00 
Upah pekerja $=$ kebutuhan tenaga kerja $\times$ harga upah lembur 1 jam

Pekerja $=2,073 \times \operatorname{Rp} 15.000,00=R p 31.104,19$

Tukang $=2,073 \times \operatorname{Rp} 20.625,00=R p 42.768,26$

Kepala tukang $=0,207 \times \mathrm{Rp} 23.437,50=\mathrm{Rp}$ 4.860,03

Mandor $=0,118 \times \operatorname{Rp} 22.500,00=\operatorname{Rp} 2.666,07$

Total upah crashing 1 jam $=\operatorname{Rp} 81.398,56$

Total upah crashing 1 jam /hari

= total upah crashing 1 jam + total upah normal perhari

$=\operatorname{Rp} 81.398,56+\operatorname{Rp} 434.125,63$

$=\operatorname{Rp} 515.524,19$

Total upah crashing 1 jam

$=$ total harga material+(total upah crashing $\times$ durasi crashing)

$=\mathrm{Rp} 101.698 .261,87+(\mathrm{Rp} 515.524,19 \times$ 25,17)

$=\operatorname{Rp} 114.674 .005,71$

Contoh perhitungan slope pada analisis microsoft project 2010 untuk pekerjaan Pembesian Beton Bored Pile dengan lembur 1 jam :

Nilai slope

$=\frac{\text { Biaya percepatan-biaya normal }}{\text { durasi normal-durasi percepatan }}$

$=\frac{\operatorname{Rp~} 114,809,591.00-\operatorname{Rp~113,848,881.00}}{28-25,17}$

$=\operatorname{Rp} 339,473.50$

Contoh perhitungan total biaya dengan variasi penambahan jam lembur adalah sebagai berikut:

Pekerjaan $=$ Pembesian beton bored pile

Durasi percepatan $=114,47$ hari

Biaya langsung

$=$ Biaya langsung + Selisih biaya

$=\operatorname{Rp} 2,333,390,264.83+\operatorname{Rp} 3.648 .389 .00$

$=\operatorname{Rp} 2,337,038,653.83$

Biaya tidak langsung

$=\frac{\text { Biaya tidak langsung } \times \text { durasi percepatan }}{\text { durasi normal }}$

$=\frac{\operatorname{Rp} 205,663,342.17 \times 114,47}{140}$

$=\operatorname{Rp} 168.159 .162,70$

Total biaya

= Biaya langsung + Biaya tidak langsung

$=\operatorname{Rp} 2,337,038,653.83+\operatorname{Rp} 168.159 .162,70$

$=\operatorname{Rp} 2,505,197,816.53$
TABEL 5. Perbandingan antara biaya total dengan variasi penambahan jam lembur

\begin{tabular}{||l|l|l|l||}
\hline \hline No & $\begin{array}{c}\text { Penambahza Jam } \\
\text { Lembur }\end{array}$ & \multicolumn{1}{|c|}{$\begin{array}{c}\text { Durasi } \\
\text { (hari) }\end{array}$} & \multicolumn{1}{|c|}{$\begin{array}{c}\text { Biaya } \\
(\text { Rp })\end{array}$} \\
\hline 1 & Nomal & 140 & $2,539,053,007,00$ \\
\hline 2 & 1 & 103,82 & $2,499,501,212.29$ \\
\hline 3 & 2 & 77,39 & $2,481,520,772,34$ \\
\hline 4 & 3 & 57,52 & $2,469,661,459,99$ \\
\hline
\end{tabular}

Dari tabel 5 perbandingan biaya total dengan variasi penambahan jam lembur didapatkan untuk lembur 1 jam biaya total sebesar Rp 2.499.501.212,29 dengan durasi percepatan 103,82 hari, untuk 2 jam lembur biaya total sebesar Rp 2.481.520.772,34 dengan durasi percepatan 77,39 hari, dan untuk lembur 3 jam biaya total sebesar Rp 2.469.661.459,99 dengan durasi percepatan 57,52 hari. Dari ketiga penambahan jam lembur, didapatkan biaya dan waktu paling efektif pada penambahan jam kerja 3 jam.

\section{Penambahan Tenaga Kerja}

Penambahan tenaga kerja dilakukan dengan menghitung kembali kebutuhan tenaga kerja dari setiap pekerjaan berdasarkan oleh durasi percepatan atau durasi crashing yang dilakukan tanpa penambahan jam kerja perhari. Contoh perhitungan sebagai berikut :

a. Durasi normal

Pekerjaan $\quad=$ Pembesian Beton Bored Pile

Volume $\quad=8294.451$

Durasi normal $=28$ har

Kapasitas tenaga kerja per $\mathrm{m}^{3}$

$\mathrm{Oh}=$ Orang $/$ hari

Pekerja $=0,007$ Oh @ Rp $80.000,00$

Tukang $=0,007$ Oh @ Rp 110.000,00

Kepala tukang $=0,0007$ Oh @ Rp 125.000,00

Mandor $=0,0004$ Oh @ Rp 120.000,00

Perhitungan jumlah tenaga kerja dan upah tenaga kerja :

Jumlah tenaga kerja

$=\frac{(\text { koefisien tenaga kerja } \times \text { volume })}{\text { Durasi normal }}$

$$
\begin{aligned}
\text { Pekerja } & =\frac{(0,007 \times 8294.451)}{(28)} \\
& =2,07 \\
\text { Upah pekerja } & =2,07 \times \mathrm{Rp} 80.000,00 \\
& =\mathrm{Rp} 165.600,00 \\
\text { Tukang } & =\frac{(0,007 \times 8294.451)}{(28)} \\
\text { Upah tukang } & =2,07 \\
& =\mathrm{Rp} 227.700,00 \\
\text { Kepala tukang } & =\frac{(0,0007 \times 8294.451)}{(28)} \\
& =0,207
\end{aligned}
$$


Upah k.tukang $=0,207 \times \mathrm{Rp} 125.000,00$

$$
=\operatorname{Rp} 25.875,00
$$

Mandor $\quad=\frac{(0,0004 \times 8294.451)}{(28)}$

$$
=0,118
$$

Upah mandor $=0,118 \times \mathrm{Rp} 120.000,00$

$$
=\operatorname{Rp} 14.160,00
$$

Upah tenaga kerja dengan durasi normal : $=(\operatorname{Rp~165.600,00+Rp~227.700,00+~}$ $\operatorname{Rp} 25.875,00+\operatorname{Rp} 14.160,00) \times 28$ hari $=\operatorname{Rp} 12.133 .380,00$

b. Durasi Percepatan

Durasi percepatan $=25,17$ hari Jumlah tenaga kerja

$=\frac{(\text { koefisien tenaga kerja } \times \text { volume })}{\text { Durasi percepatan }}$

$$
\begin{aligned}
\text { Pekerja } & =\frac{(0,007 \times 8294.451)}{(25,17)} \\
& =2,31 \text { orang/hari } \\
\text { Upah pekerja } & =2,31 \times \mathrm{Rp} 80.000,00 \\
& =\mathrm{Rp} 184.800,00 \\
\text { Tukang } & =\frac{(0,007 \times 8294.451)}{(25,17)} \\
\text { Upah tukang } & =2,31 \text { orang/hari } \\
& =2,31 \times \mathrm{Rp} 110.000,00 \\
\text { Kepala tukang } & =\frac{(0,0007 \times 8294.451)}{(25,17)} \\
\text { Upah k. tukang } & =0,23 \text { orang/hari } \\
& =\mathrm{Rp} 28.750,00 \\
\text { Mandor } & =\frac{(0,0004 \times 8294.451)}{(25,17)} \\
& =0,13 \text { orang/hari } \\
\text { Upah mandor } & =0,13 \times \mathrm{Rp} 120.000,00 \\
& =\mathrm{Rp} 15.600,00
\end{aligned}
$$

Upah tenaga kerja dengan durasi percepatan (25,17 hari) :

$=(\operatorname{Rp} \operatorname{Rp} 184.800,00+\mathrm{Rp} 254.100,00+\mathrm{Rp}$

$28.750,00+\operatorname{Rp} 15.600,00) \times 25,17$ hari

$=\operatorname{Rp} 12.163 .402,00$

Selisih biaya

= Biaya percepatan - biaya normal

$=\operatorname{Rp} 12.163 .402,00-\operatorname{Rp} 12.133 .380,00$

$=\operatorname{Rp} 30.022,00$

TABeL 6. Perbandingan antara biaya total dengan variasi penambahan tenaga kerja

\begin{tabular}{||l|l|l|l||}
\hline No & $\begin{array}{c}\text { Penambahma Jam } \\
\text { Lembar }\end{array}$ & \multicolumn{1}{|c|}{$\begin{array}{c}\text { Durasi } \\
\text { (hari) }\end{array}$} & \multicolumn{1}{c||}{$\begin{array}{c}\text { Biaya } \\
\text { (Rp) }\end{array}$} \\
\hline 1 & Nomal & 140 & $2.539 .053 .607,00$ \\
\hline 2 & 1 & 103,82 & $2.486 .556 .521,65$ \\
\hline 3 & 2 & 77,39 & $2.447 .704 .212,20$ \\
\hline 4 & 3 & 57,52 & $2.418 .408 .305,45$ \\
\hline
\end{tabular}

Dari tabel perbandingan biaya total dengan variasi penambahan tenaga kerja didapatkan untuk durasi 1 jam biaya total sebesar Rp 2.486.556.521,65 dengan durasi percepatan 103,82 hari, untuk 2 jam biaya total sebesar $\mathrm{Rp}$ 2.447.704.212,20 dengan durasi percepatan 77,39 hari, dan untuk durasi 3 jam biaya total sebesar Rp 2.418.408.305,45 dengan durasi percepatan 57,52 hari. Dari ketiga penambahan tenaga kerja, didapatkan biaya dan waktu paling efektif pada penambahan tenaga kerja dengan durasi 3 jam.

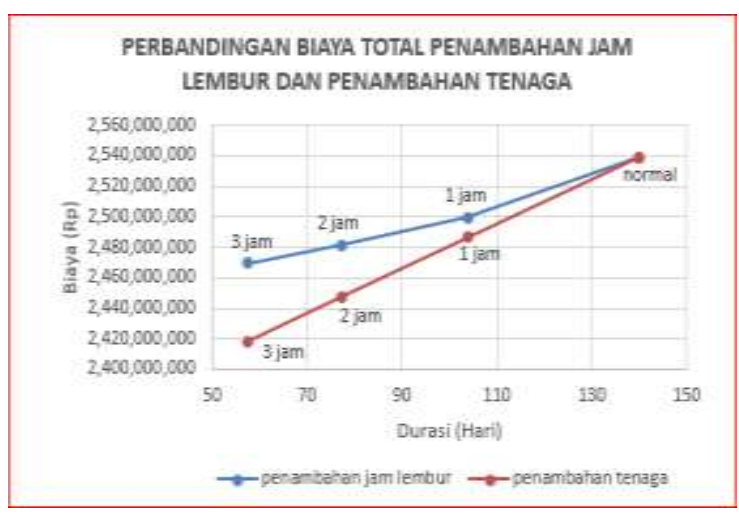

GAMBAR 8. Grafik perbandingan titik biaya normal dengan biaya penambahan jam lembur dan penambahan tenaga

Dari grafik perbandingan titik biaya normal dengan biaya penambahan jam lembur dan penambahan tenaga dapat dilihat bahwa waktu dan biaya yang paling optimal yaitu pada penambahan tenaga kerja durasi 3 jam, dengan total biaya sebesar Rp 2.418.408.305,45 dengan durasi percepatan 57,52 hari

\section{KESIMPILAN}

Berdasarkan hasil analisis data dan pembahasan yang dilakukan pada Proyek Pembangunan Gedung Olah Raga (Gor), disimpulkan sebagai berikut :

1. Perubahan biaya akibat variasi penambahan jam lembur selama 1 jam adalah lebih murah sebesar Rp 39.552.394,71 dari semula biaya normal proyek sebesar Rp 2.539.053.607,00 menjadi Rp 2.499.501.212,29. Untuk waktu lembur 2 jam perubahan biaya yang terjadi sebesar Rp 57.532.834,66 dari semula biaya normal proyek sebesar 2.539.053.607,00 menjadi Rp 2.481.520.772,34. Pada jam lembur 3 jam didapat selisih biaya paling efektif sebesar $\mathrm{Rp}$ 69.392.147,01 dari semula biaya normal proyek sebesar $\mathrm{Rp}$ 2.539.053.607,00 menjadi Rp 
2.469.661.459,99. Sedangkan perubahan waktu apabila dilakukan variasi penambahan jam lembur selama 1 jam adalah 36,18 hari dari semula waktu normal proyek 140 hari menjadi 103,82 hari. Apabila jam lembur ditambah menjadi 2 jam durasi percepatan menjadi 62,61 hari dari semula waktu normal proyek 140 hari menjadi 77,39 hari. Apabila jam lembur ditambah menjadi 3 jam durasi percepatan menjadi 82,48 hari dari semula waktu normal proyek 140 hari menjadi 57,52 hari.

2. Perubahan biaya akibat variasi penambahan tenaga kerja selama 1 jam adalah lebih murah sebesar $\mathrm{Rp}$ 52.497.085,35 dari semula biaya normal proyek sebesar $\mathrm{Rp}$ 2.539.053.607,00 menjadi $\mathrm{Rp}$ 2.486.556.521,65. Untuk penambahan tenaga kerja 2 jam perubahan biaya yang terjadi sebesar $\mathrm{Rp}$ 91.349.394,80 dari semula biaya normal proyek sebesar 2.539.053.607,00 menjadi $\mathrm{Rp}$ 2.447.704.212,20. Pada penambahan tenaga kerja 3 jam didapat selisih biaya paling efektif sebesar Rp 120.645.301,55 dari semula biaya normal proyek sebesar $\mathrm{Rp}$ 2.539.053.607,00 menjadi $\mathrm{Rp}$ 2.418.408.305,45. Sedangkan perubahan waktu apabila dilakukan variasi penambahan tenaga kerja selama 1 jam adalah 36,18 hari dari semula waktu normal proyek 140 hari menjadi 103,82 hari. Apabila jam lembur ditambah menjadi 2 jam durasi percepatan menjadi 62,61 hari dari semula waktu normal proyek 140 hari menjadi 77,39 hari. Apabila jam lembur ditambah menjadi 3 jam durasi percepatan menjadi 82,48 hari dari semula waktu normal proyek 140 hari menjadi 57,52 hari.

3. Biaya dan durasi paling optimal didapat pada penambahan tenaga kerja selama 3 jam, dibandingkan menambah jam lembur. Yaitu dengan biaya optimal proyek sebesar Rp 2.418.408.305,45 dan durasi optimal proyek selama 57,52 hari.

\section{DAFTAR PUSTAKA}

Dwijono, D., 2017, Optimalisasi Waktu Percepatan dan Biaya Kegiatan di dalam Metode Jalur Kritis dengan Pemrograman Linier, Jurnal Terapan Teknologi Informatika, 1(1), pp. 1-9.

Dipohusodo, I., 1996, Manajemen Proyek Dan Konstruksi, Yogyakarta: Kanisius.
Frederika, A., 2010, Analisis Percepatan Pelaksanaan dengan Menambah Jam Kerja Optimum pada Proyek Konstruksi (Studi Kasus Proyek Pembangunan Super Villa Peti TengetBadung, Jurnal

Ilmiah Teknik Sipil, 14(2), pp. 113126.

Ikhtisholiyah, 2017, Analisis Penerapan Manajemen Waktu dan Biaya pada Proyek Pembangunan Gedung Kuliah Teknik Listrik Industri Politeknik Negeri Madura (POLTERA), Zeta Math Journal, 3(1), pp. 14-21.

Kareth, M., 2012, Analisis Optimalisasi Waktu dan Biaya Dengan Program Primavera 6.0 (Studi Kasus Proyek Pembangunan Puri Kelapa Gading), Jurnal Sipil Statik, 1(1), pp. 53-59.

Khodijah, N.S., Yahdin, S., Dewi, N.R., 2013, Optimalisasi Pelaksanaan Proyek Pembangunan Persinyalan Elektrik di Stasiun Kertapati dengan Penerapan Metode Crash Program, Jurnal Penelitian Sains, 16(2A), pp. 65-74.

Pawiro, D.A., Suharyanto, Atmojo, P.S., 2014, Optimalisasi Biaya dan Waktu dalam Penyusunan Jadwal Pelaksanaan Proyek (Studi Kasus Proyek Pembangunan Gedung Pusat Kegiatan Mahasiswa Universitas Diponegoro Semarang,. Jurnal Media Komunikasi Teknik Sipil, 20(2), pp. 103-108.

Priyo, M., Sumanto, A., 2016, Analisis Percepatan Waktu dan Biaya Proyek Konstruksi dengan Penambahan Jam Kerja (Lembur) Menggunakan Metode Time Cost Trade Off (Studi Kasus Pembangunan Prasarana Pengendalian Banjir), Jurnal Ilmiah Semesta Teknika, 19(1), pp. 1-15.

Simatupang, J.S., 2015, Pengaruh Percepatan Durasi Terhadap Waktu Pada Proyek Konstruksi (Studi Kasus Pembangunan Persekolahan Eben Haezar Manado), Jurnal Sipil Statik, 3(5), pp. 281-291.

Soeharto, I., 1995, Manajemen Proyek Dari Konseptual Sampai Operasional, Jakarta: Erlangga.

Telaumbanua, T.A., 2017, Perencanaan Waktu Penyelesaian Proyek Toko Modisland Manado dengan Metode CPM, Jurnal Sipil Statik, 5(8), pp. 549-557. 
Wowor, F., 2013, Aplikasi Microsoft Project dalam Pengendalian Waktu Pelaksanaan Pekerjaan Proyek, Jurnal Sipil Statik, 1(8), pp. 543-548.

PENULIS:

\section{Mandiyo Priyo}

Program Studi Teknik Sipil, Fakultas Teknik, Universitas Muhammadiyah Yogyakarta, Yogyakarta.

Email: pmandiyo@yahoo.com

Meiki Risa Anggriani Paridi

Program Studi Teknik Sipil, Fakultas Teknik, Universitas Muhammadiyah Yogyakarta, Yogyakarta.

Email: meiki.anggriani.2014@ft.umy.ac.id 